Article

\title{
Numerical Investigation on the Performance of Two-Throat Nozzle Ejectors with Different Mixing Chamber Structural Parameters
}

\author{
Fatong Jia ${ }^{1}\left(\mathbb{D}\right.$, Dazhang Yang $^{1}$ and Jing Xie ${ }^{1,2,3, *(D)}$ \\ 1 College of Food Science and Technology, Shanghai Ocean University, Shanghai 201306, China; \\ ftjia3356@163.com (F.J.); dzyang@shou.edu.cn (D.Y.) \\ 2 National Experimental Teaching Demonstration Center for Food Science and Engineering, \\ Shanghai 201306, China \\ 3 Shanghai Professional Technology Service Platform on Cold Chain Equipment Performance and Energy \\ Saving Evaluation, Shanghai 201306, China \\ * Correspondence: jxie@shou.edu.cn; Tel.: +86-021-6190-0365
}

Citation: Jia, F.; Yang, D.; Xie, J. Numerical Investigation on the Performance of Two-Throat Nozzle Ejectors with Different Mixing Chamber Structural Parameters. Energies 2021, 14, 6900. https:// doi.org/10.3390/en14216900

Academic Editor: Adrián Mota Babiloni

Received: 30 August 2021 Accepted: 19 October 2021 Published: 21 October 2021

Publisher's Note: MDPI stays neutral with regard to jurisdictional claims in published maps and institutional affiliations.

Copyright: (c) 2021 by the authors. Licensee MDPI, Basel, Switzerland. This article is an open access article distributed under the terms and conditions of the Creative Commons Attribution (CC BY) license (https:// creativecommons.org/licenses/by/ $4.0 /)$.

\begin{abstract}
In this study, the effects of the mixing chamber diameter $\left(D_{m}\right)$, mixing chamber length $\left(L_{m}\right)$ and pre-mixing chamber converging angle $\left(\theta_{p m}\right)$ were numerically investigated for a two-throat nozzle ejector to be utilized in a $\mathrm{CO}_{2}$ refrigeration cycle. The developed simulated method was validated by actual experimental data of a $\mathrm{CO}_{2}$ ejector in heat pump water heater system from the published literature. The main results revealed that the two-throat nozzle ejectors can obtain better performance with $D_{m}$ in the range of 8-9 $\mathrm{mm}, L_{m}$ in the range of 64-82 $\mathrm{mm}$ and $\theta_{p m}$ at approximately $60^{\circ}$, respectively. Deviation from its optimal value could lead to a poor operational performance. Therefore, the mixing chamber structural parameters should be designed at the scope around its optimal value to guarantee the two-throat nozzle ejector performance. The following research can be developed around the two-throat nozzle geometries to strengthen the ejector performance.
\end{abstract}

Keywords: ejector; entrainment ratio; two-throat nozzle; refrigeration; CFD simulation; $\mathrm{CO}_{2}$

\section{Introduction}

Sustainable economy and societal development are easily limited by energy shortages and environmental pollution [1]. In terms of refrigeration systems, the use of traditional CFCs and HCFCs refrigerants has leaded to the ozone layer being destroyed and greenhouse effects [2]. For the betterment of the environment, the natural refrigerant $\mathrm{CO}_{2}$ with zero ODP and low GWP is chosen as a desired substitution for these refrigerants by virtue of its environmental friendliness [3]. Currently, research works on $\mathrm{CO}_{2}$ are being performed extensively in areas such as supermarkets [4,5], heat pump units [6-8], vehicles [9,10], light commercial refrigeration [11,12], tumble dryers [13,14], chillers [15]. $\mathrm{CO}_{2}$ systems are widely promoted for their incomparable advantages. The $\mathrm{CO}_{2}$ vapor compression refrigeration cycle unavoidably works under trans-critical conditions because of its low critical temperature. The utilization of an expansion valve in trans-critical $\mathrm{CO}_{2}$ refrigeration systems would cause a larger irreversibly throttling loss due to the greater pressure drop compared with that of other traditional refrigeration systems [16]. For the sake of enhancing the performance $\mathrm{CO}_{2}$ refrigeration system, ejectors began to be used as promising devices to reduce throttling losses [17].

Ejectors have remarkable advantages of structural simplicity, low cost, no moving parts, being basically maintenance-free devices that employ environmentally friendly refrigerants such as $\mathrm{CO}_{2}[18,19]$. The basic structure of an ejector consists of a primary nozzle, pre-mixing chamber, mixing chamber and diffuser. They work as follows: the primary flow (PF) is depressurized and accelerated inside the nozzle. Next, the PF with high velocity and low-pressure flows into pre-mixing chamber to form a low pressure 
area, where the secondary flow (SF) is entrained. The PF and SF mix with each other in the mixing chamber for the function of the exchange of kinetic energy. In the end, the kinetic energy of the mixed flow starts to be transformed to pressure potential energy in the diffuser. Part of energy can be recovered during the throttling process by using an ejector. In 2008, the Japanese company DENSO firstly advanced the two-throat nozzle ejector with two Laval nozzles in series. Subsequently, Kang et al. [20] experimentally confirmed the smaller nozzle distance and first nozzle divergence angle at $8^{\circ}$ provided better performance for two-throat nozzle ejectors in a ejector refrigeration system. Figure 1 presents the operating principles of the two-throat nozzle and Laval nozzle. The conventional ejector nozzle is a section of a Laval nozzle, where the refrigerant can only be vaporized at the end of the nozzle. This causes the problem that the droplets in the middle part are large and the flow speed cannot be increased well. The two-throat nozzle has two Laval nozzles in series. The refrigerant is depressurized and bubbles are created at the first section of the nozzle. Subsequently, the bubbles are ruptured due to the increase in area and pressure and bubbles nucleus are formed. The second section of the nozzle promotes rapid expansion and makes the droplets smaller to make the refrigerant be a homogeneous flow. This homogeneous flow is similar to a single-phase flow, which can improve the nozzle efficiency.
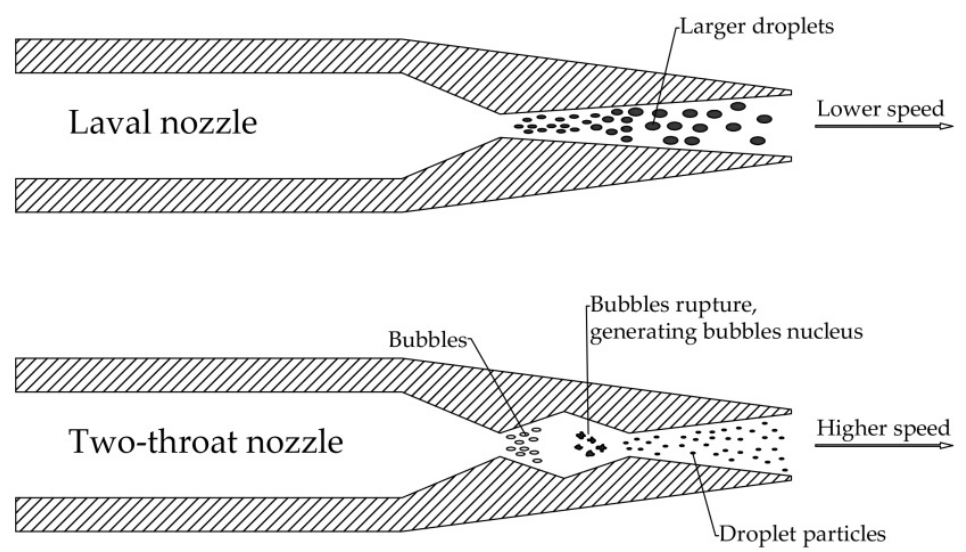

Figure 1. Schematic diagram of a two-throat nozzle and a Laval nozzle.

Ejectors exert considerable influence on ejector refrigeration cycles due to their entrainment performance [21]. Although there is an increasing trend of using ejectors in refrigeration systems, a lot of works need to be done on the optimization of ejector performance [22]. There exist some studies using unconventional nozzles to improve ejector performance by modify features such as the shape, quantity or with swirl generators. Chang and Chen [23] developed a petal nozzle to improve the pressure lift and entrainment performance of ejectors. Yang et al. [24] numerically implemented a comparison among five nozzle structures under the same working conditions including conical, elliptical, square, rectangular and cross-shaped nozzles. The results showed that the structure of the nozzle affected the $E r$ and back pressure greatly, and the cross-shaped nozzle increased $\mathrm{Er}$ by $9.1 \%$ compared with a standard circular nozzle. Their work found the conical nozzle performed better compared with the other nozzle shapes as far as critical back pressures were concerned. Wang et al. [25] found that the nozzle exit position and the nozzle throat diameter exerted marked effects on the efficiency of novel two-phase ejectors. Banu and Mani [26] added a swirl generator structure to the ejector nozzle, and the simulated outcomes showed that the $E r$ was increased by $15 \%$ compared with a traditional ejector, however the nozzle with swirl generator has a complex structure making it difficult to machine. Zhou et al. [27] developed a new type of ejector with double nozzle to optimize refrigeration systems by comparing the new cycle with the conventional ejector refrigeration system and the standard refrigeration system using a mathematical model. The results indicated that the COP of the new cycle was increased by $22.9-50.8 \%$ in contrast to the standard refrigeration 
system, and $10.5-30.8 \%$ in comparison to the conventional ejector refrigeration system. Rao et al. [28] increased $E r$ by up to 30\% with the aid of tip ring supersonic nozzles and elliptic sharp tipped shallow lobed nozzles in supersonic ejectors. Although significant numerical studies were carried out for the optimization of nozzles, the works were rarely developed experimentally.

The mixing chamber is one of the main objects of ejector design optimization. The optimization of conventional ejector mixing chamber geometric parameters has been conducted numerically and experimentally to enhance ejector performance and ejector refrigeration system performance [29-31]. Kim et al. [32] and Wang et al. [33] revealed that the mixing chamber geometries strongly affected ejector performance. Hou et al. [34] and Nakagawa et al. [35] obtained the optimal mixing chamber length $\left(L_{m}\right)$ to make ejectors achieve better pressure lift and Er. Zhang et al. [36] and Wu et al. [37] numerically analyzed the ejector performance by changing $L_{m}$ and other geometries and studied the flow phenomena inside the ejector. Dong et al. [38,39] investigated the effects of $L_{m}$ with the assistance of Mach numbers in an ejector refrigeration system. However, their research works failed to deeply reveal the two-phase flow mechanism with different mixing chamber geometries.

Summarizing the above studies, developing the nozzle is an effective way to improve the performance of an ejector. In previous works the nozzles were rarely improved from the perspective of two-phase flow. Although the two-throat nozzle structure may make the fluid flow from the nozzle more homogeneous and improve ejector performance, the research on two-throat nozzle ejector is still in a preliminary stage. Given the inadequacy of reports on the mixing chamber geometries of two-throat nozzle ejectors, in this study, the performance of two-throat nozzle ejectors varied with different mixing chamber structural parameters including mixing chamber diameter $\left(D_{m}\right), L_{m}$ and pre-mixing chamber convergence angle $\left(\theta_{p m}\right)$ was analyzed under different operation conditions by a computational fluid dynamics (CFD) method. The simulated method was verified by using experimental data from the published literature [40] and displayed acceptable accuracy. The results were summarized to provide guidance for the design of mixing chamber structures for two-throat nozzle ejectors.

\section{Numerical Calculation Model}

\subsection{Physical Model}

This study aimed to investigate the performance of two-throat nozzle ejectors employed in a vessel refrigeration system, which was installed between the intercooler and gas cooler to execute the first throttling process. The elementary structural parameters for two-throat nozzle ejector were computed based on the gas dynamic function method under certain design conditions $\left(P_{p}\right.$ of $9.3 \mathrm{MPa}, T_{p}$ of $35^{\circ} \mathrm{C}, P_{s}$ of $4.1 \mathrm{MPa}, T_{s}$ of $12{ }^{\circ} \mathrm{C}, P_{c}$ of 4.7 MPa). On the basis of the previous design work by Kang et al. [20], the same parameter as first throat diameter was applied for the second throat diameter. A two-throat nozzle ejector includes a two-throat nozzle, suction chamber, pre-mixing chamber, mixing chamber and diffuser. The main structural diagram and parameter details for the two-throat nozzle ejector are presented in Figure 2 and Table 1, respectively.

Table 1. Key structural sizes for the two-throat nozzle ejector.

\begin{tabular}{cccc}
\hline Geometric Objects & Value $/ \mathbf{m m}$ & Geometric Objects & Value/mm \\
\hline Nozzle inlet diameter $/ D_{p}$ & 17 & Diameter of the second throat $/ D_{s t}$ & 3.4 \\
Suction nozzle diameter $/ D_{s}$ & 34 & Second nozzle outlet diameter $/ D_{s o}$ & 3.6 \\
Diameter of the first throat $/ D_{f t}$ & 3.6 & Diffuser outlet diameter $/ D_{d}$ & 28 \\
First nozzle outlet diameter $/ D_{f o}$ & 4.8 & Length of diffuser $/ L_{d}$ & 72 \\
\hline
\end{tabular}




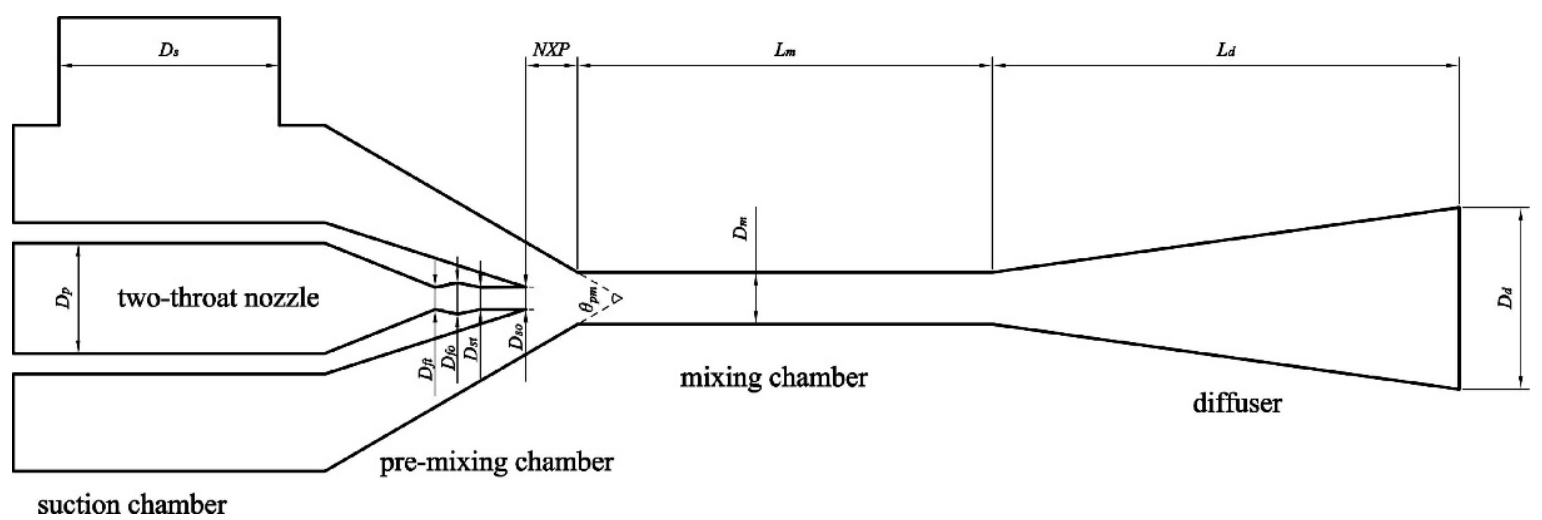

Figure 2. Structural diagram of the two-throat nozzle ejector.

\subsection{Governing Equations}

To simplify the numerical calculation, on basis of the characteristics of the flow inside the ejector and the aims of this study, the following assumptions were made:

(1) The expansion process of flow kept isentropic.

(2) The ejector inner wall surface was smooth and adiabatic.

(3) The flow eventually kept steady.

(4) The state of secondary inlet flow was ideal-gas.

(5) Both flows were saturated.

On account of above assumptions, the governing equations including mass, momentum and energy utilized to a control cell in the computational domain are presented on the below:

Mass equation:

$$
\frac{\partial \rho}{\partial t}+\frac{\partial}{\partial x_{i}}\left(\rho u_{i}\right)=0
$$

Momentum equation:

$$
\frac{\partial\left(\rho u_{i}\right)}{\partial t}+\frac{\partial}{\partial x_{i}}\left(\rho u_{i} u_{j}\right)=\frac{\partial \tau_{i j}}{\partial x_{j}}-\frac{\partial p}{\partial x_{i}}
$$

Energy equation:

$$
\frac{\partial(\rho E)}{\partial t}+\frac{\partial}{\partial x_{i}}\left(u_{i}(\rho E+P)\right)=\vec{\nabla} \cdot\left(\alpha_{e f f} \frac{\partial T}{\partial x_{i}}+u_{j}\left(\tau_{i j}\right)\right)
$$

where the stress tensor $\tau_{i j}$ in Equations (2) and (3) can be expressed as:

$$
\tau_{i j}=\mu_{e f f}\left(\frac{\partial u_{i}}{\partial x_{j}}+\frac{\partial u_{j}}{\partial x_{i}}-\frac{2}{3} \frac{\partial u_{k}}{\partial x_{i}} \delta_{i j}\right)
$$

where $\rho$ is the density, $P$ is the static pressure, $u$ is the vector velocity, $t$ is the time, $\tau$ is the viscous stress, $E$ is the total energy, $T$ is the static temperature, $\alpha_{e f f}$ is the effective heat conductivity, $i$ and $j$ are the space vector directions, $\mu_{e f f}$ is the effective dynamic viscosity and $\delta_{i j}$ is the Kronecker delta function.

\subsection{Turbulence Model}

The standard, the standard realizable and renormalization-group (RNG) $k$ - $\varepsilon$ models on the basis of Boussinesq hypothesis are employed to handle above governing equations:

$$
-\rho \overline{u_{i}^{\prime} u_{j}^{\prime}}=\mu_{t}\left(\frac{\partial u_{i}}{\partial u_{j}}+\frac{\partial u_{j}}{\partial x_{i}}\right)-\frac{2}{3}\left(\rho k+\mu_{t} \frac{\partial u_{i}}{\partial x_{j}}\right) \delta_{i j}
$$




\subsection{Simulation Settings}

The setting for boundary conditions was that the primary and secondary flow inlet were pressure inlets, the ejector outlet was the pressure outlet, and the wall was no-slip and an adiabatic solid wall. The refrigerant $\mathrm{CO}_{2}$ was chose as working fluid. The primary flow properties parameters of $\mathrm{CO}_{2}$ were confirmed based on NIST REFPROP libraries and the secondary flow was assumed as an ideal gas.

A hexahedral grid mesh was generated using ICEM CFD 19.0 for the two-throat nozzle ejector 3D model. As shown in Figure 3, the mesh model was divided into around 260,000 cells, and the generated mesh around the nozzle and pre-mixing chamber was intensified to make a more precise prediction for the complex flows. The simulated computation was executed by Fluent 19.0, which was based on a finite volume approach. The nonlinear control equations were discretized by the solver in the way of pressurebased, the turbulent flows were controlled by standard $k-\varepsilon$ model, and the standard wall function was applied for the near-wall treatment. The second-order upwind scheme was implemented to discretize convective terms. The two-phase flow was assumed to be in homogeneous equilibrium. The residuals for all the equations were below $1 \times 10^{-6}$. The specific simulation settings are listed in Table 2.

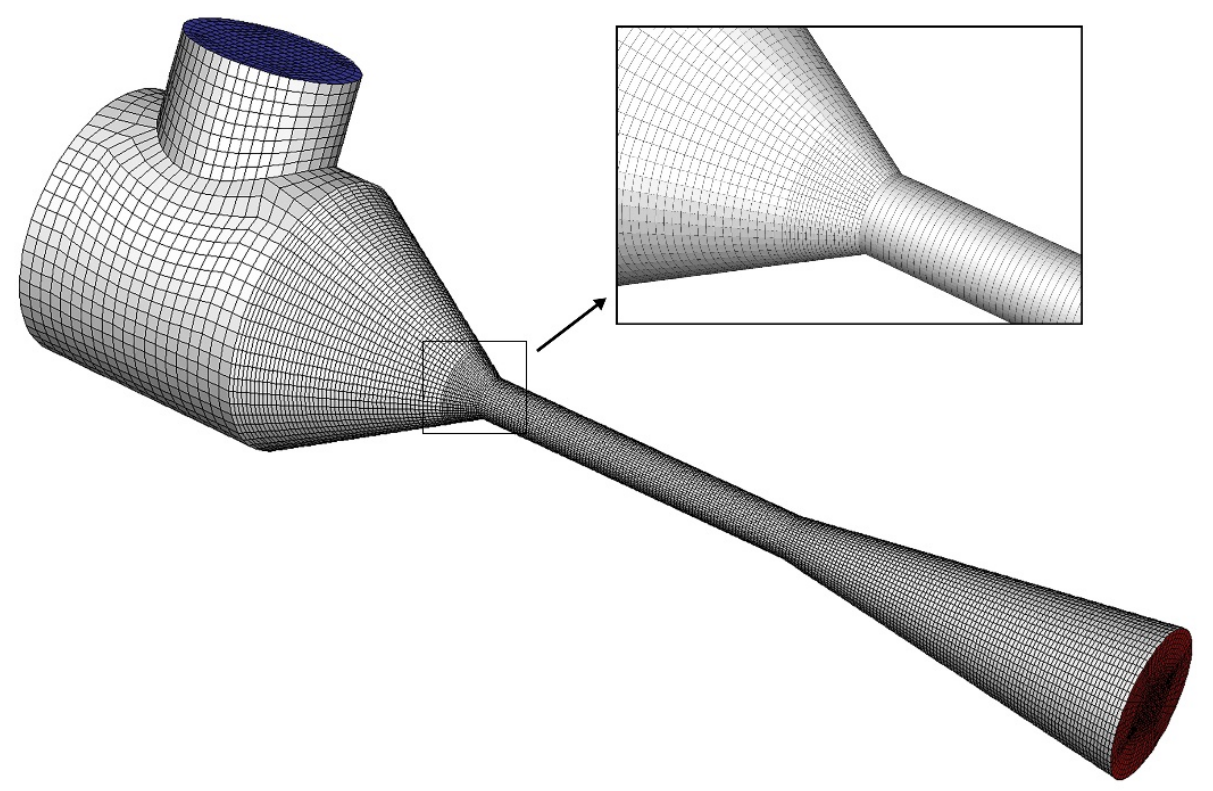

Figure 3. Grid of the two-throat nozzle ejector 3D model.

Table 2. Simulation parameters.

\begin{tabular}{cc}
\hline Primary flow inlet & Pressure inlet \\
Secondary flow inlet & Pressure inlet \\
Outlet & Pressure outlet \\
Wall & No-slip \\
Solver & Pressure-based \\
Time & Steady \\
Turbulence model & Standard $k-\varepsilon$ \\
Near-wall treatment & Standard wall functions \\
Materials & $\mathrm{CO}_{2}$ \\
Pressure-velocity coupling & SIMPLEC $^{\text {Convective terms }}$ \\
Convergence criteria & Second-order upwind \\
Cond & $1 \times 10^{-6}$ \\
\hline
\end{tabular}




\subsection{Grid Independence Test and Simulation Method Validation}

The grids of five different quantities were generated for the calculation model, and the results were calculated using same structural ejector model and solution. Figure 4 presents the relationship between $\mathrm{Er}$ and grid quantities. From the figure, it is observed that the $E r$ increased with the enlargement of grid quantities firstly, and when the grid quantities were more than 250 thousand, Er nearly kept steady for the increment in grid quantities. For best accuracy and least computational time, the grid division quantity of the calculation model was chosen to be approximately 250,000.

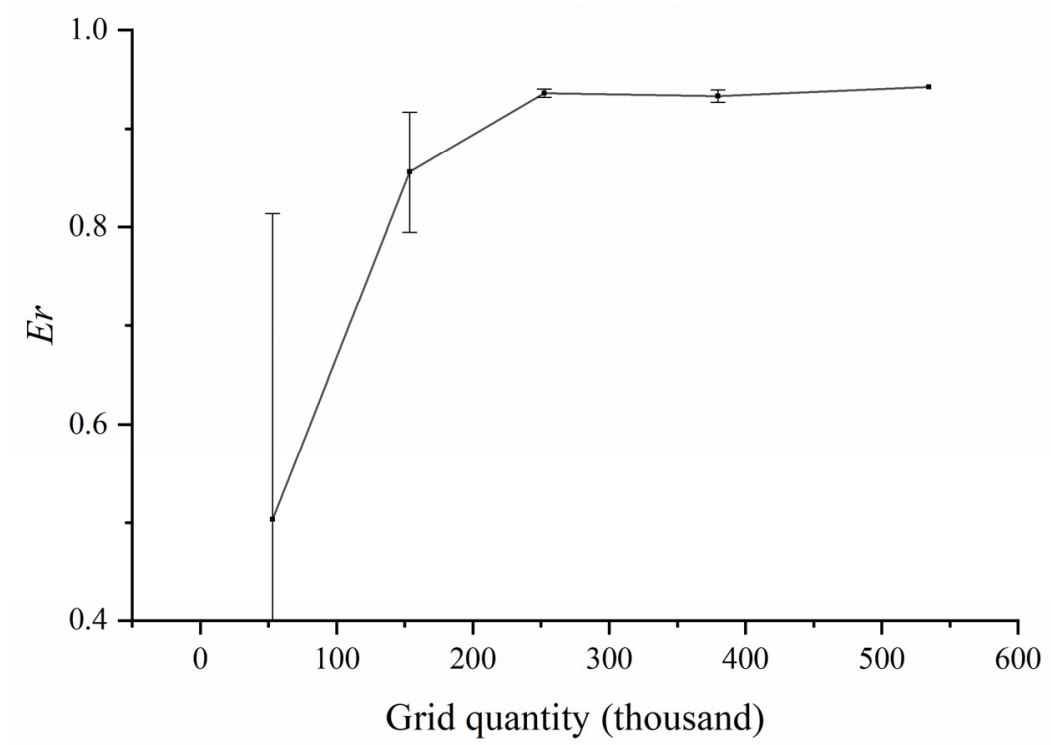

Figure 4. Variation of Er with the number of grids.

To validate the simulation method, an ejector calculation model possessing the same size as an experimental ejector described in the literature [40] was established, where Figure 5 presents its structural dimensions. The referenced ejector was utilized in a $\mathrm{CO}_{2}$ heat pump water heater system, where the experimental data including primary mass flow rates $\left(\omega_{p}\right)$ and secondary mass flow rates $\left(\omega_{s}\right)$ were recorded with the increase of $P_{s}$ under fixed conditions ( $P_{p}$ of $9.3 \mathrm{MPa}, T_{p}$ of $35^{\circ} \mathrm{C}, T_{s}$ of $12{ }^{\circ} \mathrm{C}, P_{c}$ of $4.7 \mathrm{MPa}$ ). The measured quantity uncertainties of the literature are listed in Table 3 . The range uncertainties of the $E r$ are approximately from $\pm 0.023 \mathrm{~kg} \cdot \mathrm{s}^{-1}$ to $\pm 0.034 \mathrm{~kg} \cdot \mathrm{s}^{-1}$. A comparison for $E r$ between CFD method and experimental data outcomes is shown in Figure 6. The data indicates that the maximum error of Er between simulation and experiment is only 8.9\%, indicating that the accuracy of the simulation method is satisfactory.

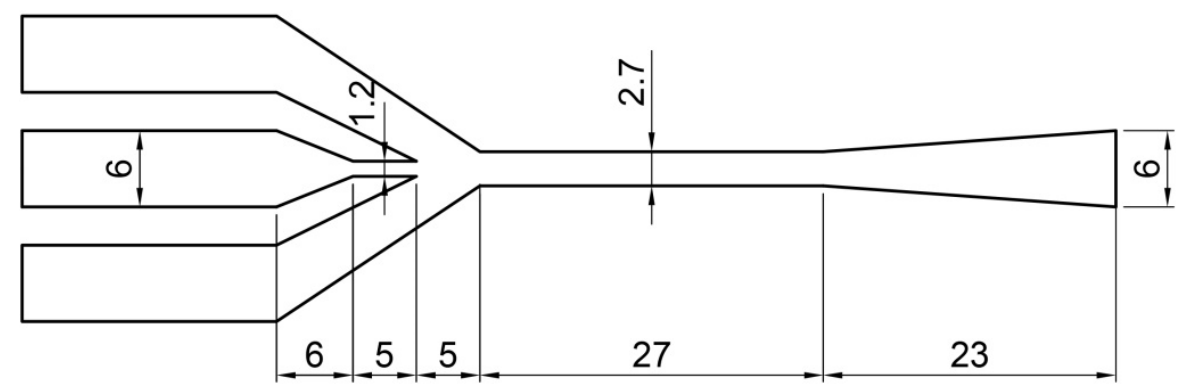

Figure 5. Structural sizes of ejector from the published literature [40]. 
Table 3. Measurement uncertainties of instrument from the published literature [40].

\begin{tabular}{ccc}
\hline Parameters & Uncertainty & Unit \\
\hline Temperature & \pm 0.5 & ${ }^{\circ} \mathrm{C}$ \\
Pressure (refrigerant) & \pm 0.032 & $\mathrm{MPa}$ \\
Mass flow rate (refrigerant) & \pm 0.001 & $\mathrm{Kg} \cdot \mathrm{s}^{-1}$ \\
\hline
\end{tabular}

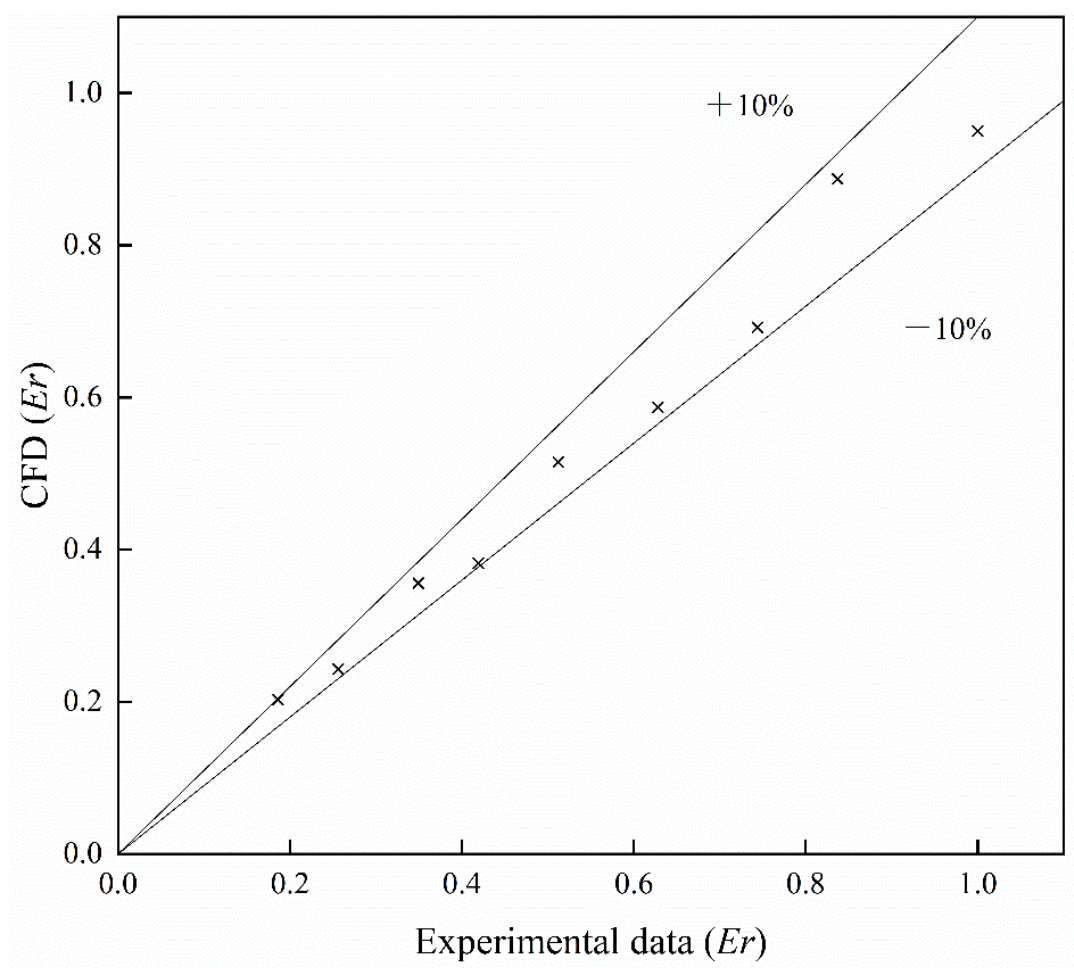

Figure 6. The comparison of $E r$ between CFD and experimental data from the published literature [40].

\section{Results and Discussion}

The ejector design process aim is to acquire a high-level mass $E r$ at a settled pressure recovery value to ensure the high-efficiency operation of ejector [41]. Er, as a significant indicator for ejector performance evaluation, reflects the entrainment capacity. The $E r$ is defined as the $\omega_{s}$ to the $\omega_{p}$ :

$$
E r=\frac{\omega_{s}}{\omega_{p}}
$$

The main purpose of this study is to investigate the influence of the mixing chamber structural parameters including $L_{m}, D_{m}$ and $\theta_{p m}$ on the two-throat nozzle ejector performance under different operation conditions. The primary flow inlet pressures $\left(P_{p}\right)$ were determined to vary from 8.9 to $9.5 \mathrm{MPa}$, the back pressure $\left(P_{c}\right)$ was fixed at $4.7 \mathrm{MPa}$, and the secondary flow inlet pressure $\left(P_{S}\right)$ was fixed at $4.1 \mathrm{MPa}$. Table 4 presents the details of the ejector sizes changes in this study.

Table 4. Size changes for ejector.

\begin{tabular}{cccccc}
\hline & Pressure & \multicolumn{3}{c}{ Structural Parameter } \\
\hline$P_{p}(\mathrm{MPa})$ & $P_{s}(\mathrm{MPa})$ & $P_{c}(\mathrm{MPa})$ & $D_{m}(\mathrm{~mm})$ & $L_{m}(\mathrm{~mm})$ & $\theta_{p m}\left({ }^{\circ}\right)$ \\
\hline $8.9 \sim 9.5$ & 4.1 & 4.7 & $6.0 \sim 10.0$ & $52 \sim 94$ & $49.7 \sim 69.0$ \\
\hline
\end{tabular}




\subsection{Effects of Mixing Chamber Diameter on the Performance of Two-Throat Nozzle Ejector}

As presented in Figure 7, the variations of $E r$ in response to the changes in $D_{m}$ are summarized under different $P_{p}$ values. It is obvious from the figure that the $E r$ over the entire range of $P_{p}$ increases initially and then decreases $D_{m}$ increases. A similar trend in $E r$ was summarized by Fu et al. [1]. In the simulated pressure ranges, the curves representing $E r$ reach their peak values from 0.85 to 0.97 as $D_{t}$ increases from $8 \mathrm{~mm}$ to $9 \mathrm{~mm}$. The broken line shows there exists a tendency that the optimum $D_{m}$ increases for the rise of $P_{p}$. The figure reveals that the similar value around $0.55 \mathrm{in} E r$ among each case as the $D_{m}$ is $6 \mathrm{~mm}$ initially, then the differences in $E r$ are getting more and more obvious for the increment of $D_{m}$ from $6 \mathrm{~mm}$ to $10 \mathrm{~mm}$, which means that the effects of $P_{p}$ on $E r$ are also affected by $D_{m}$. The outcomes indicate that the parameter $D_{m}$ is of great significance to the two-throat nozzle ejector performance and needs to be cautiously designed within the optimum range.

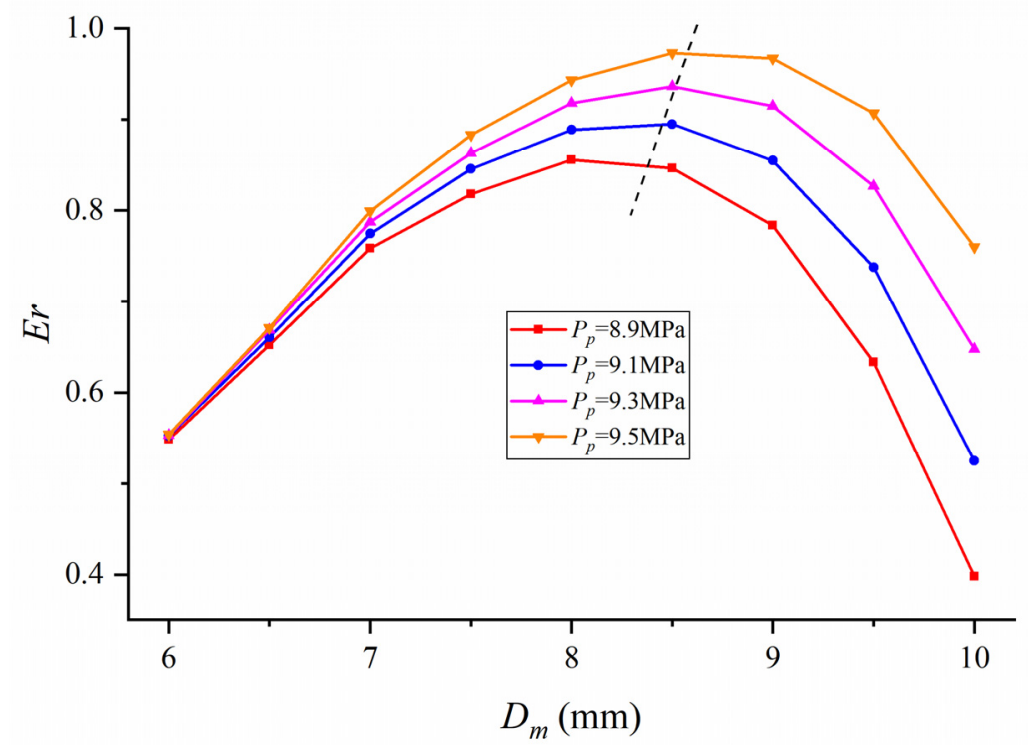

Figure 7. Variations of $E r$ with different $D_{m}$ and $P_{p}\left(L_{m}\right.$ of $64 \mathrm{~mm}, \theta_{p m}$ of $\left.60.4^{\circ}\right)$.

To further explain the phenomena illustrated in Figure 7, the variations for axial static pressures at $P_{p}$ of $9.3 \mathrm{MPa}$ are illustrated in Figure 8 . It is observed that there exists almost no distinction for axial static pressures among all the cases before the nozzle outlet. The differences of axial static pressures among the cases can be seen when the PF flows into the pre-mixing chamber. With increasing $D_{m}$, the axial static pressures for all cases fall firstly and then rise to a different degree inside the pre-mixing chamber. From the pre-mixing chamber section, it is noticed that the rates of increase for axial static pressures decline in response to the enlargement of $D_{m}$, which indicates that a better mixing between PF and SF has occured. The reason may be that the enlargement of $D_{m}$ leads to the increase of flow area, resulting in more SF flooding into the pre-mixing chamber to exchange energy with PF. As the $D_{m}$ increases more than $8.5 \mathrm{~mm}$, the pre-mixing chamber fails to form a relatively lower pressure area to entrain more $\mathrm{SF}$, then the entrainment performance of the two-throat nozzle ejector becomes worse.

Figure 9 depicts the partial fields of velocity in radial direction for simulated ejectors as $D_{m}$ changes from $6 \mathrm{~mm}$ to $10 \mathrm{~mm}$ at $P_{p}$ of $9.3 \mathrm{MPa}$. The broken line marks the location of the nozzle outlet. The figure displays the similarity in velocity fields for all the cases inside the two-throat nozzle. It is can be seen that there are not many differences in the velocity fields of the primary flows inside the pre-mixing chamber over the entire cases, but dramatic differences in SF occur on both sides. It is observed that the distance of relative high-speed flow on both sides of SF lengthens initially and then shortens with the further enlargement in $D_{m}$, which means that the SF of middle size $D_{m}$ is well accelerated as compared to a smaller or bigger one. This phenomenon exactly proves the trend of $E r$ in 
Figure 7. In addition, the figure shows that the PF of bigger $D_{t}$ maintains high velocity for a shorter distance at mixing chamber, which is confirmed by the pressure differences inside the mixing chamber shown in Figure 8. A possible reason behind this variation could be that different levels of mixing occur between PF and SF.

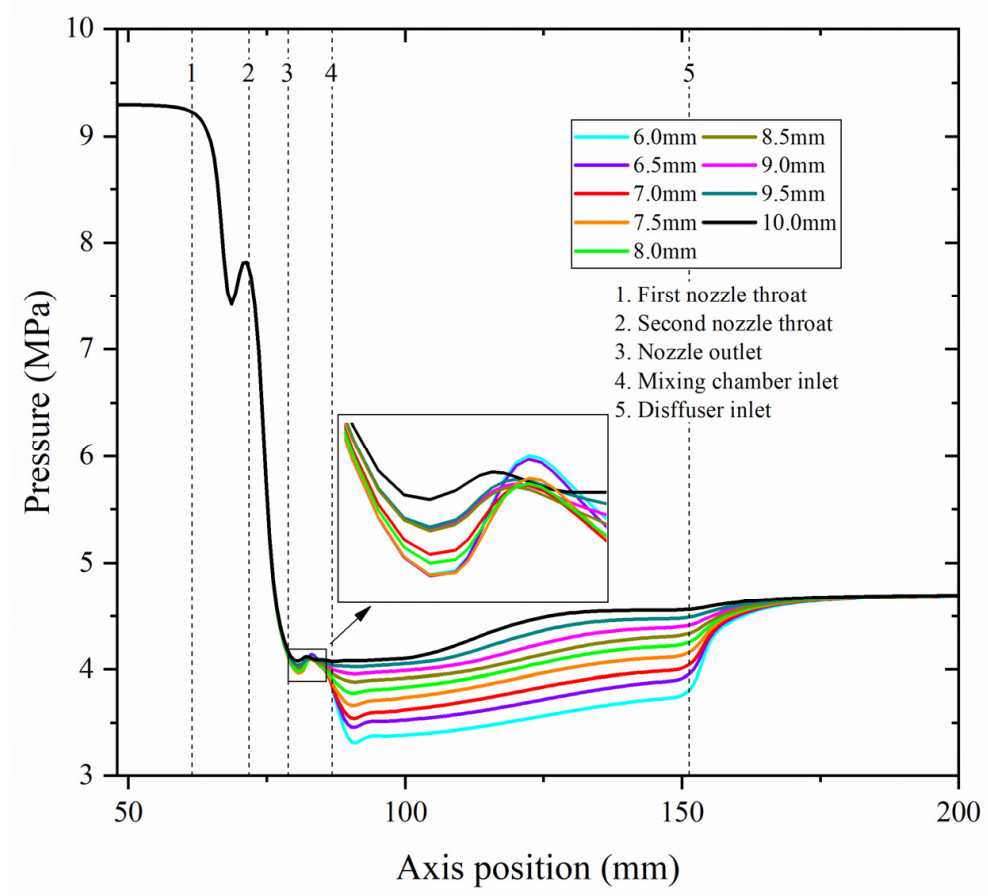

Figure 8. Variations of axial static pressures under different $D_{m}\left(P_{p}\right.$ of $\left.9.3 \mathrm{MPa}\right)$.

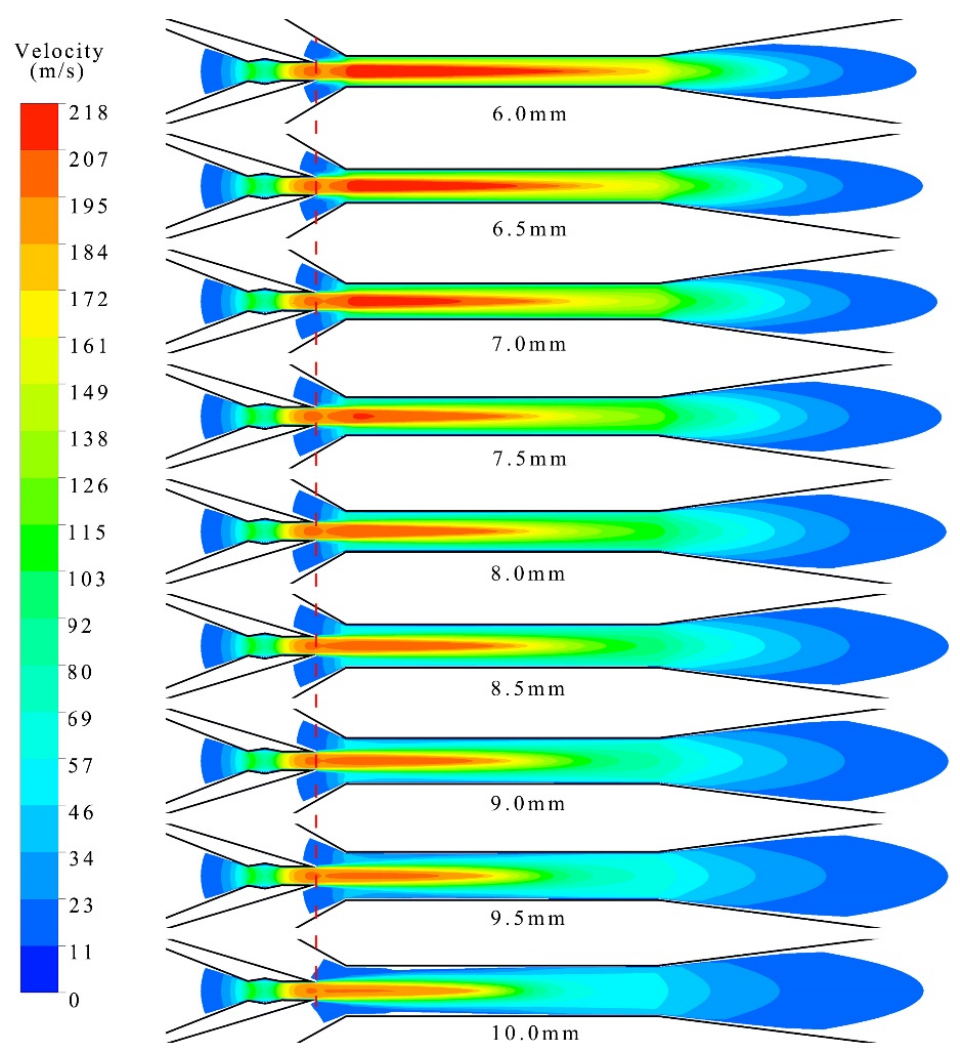

Figure 9. Fields of velocity under different $D_{m}\left(P_{p}\right.$ of $\left.9.3 \mathrm{MPa}\right)$. 


\subsection{Effects of Mixing Chamber Length on the Performance of Two-Throat Nozzle Ejector}

The variations of $E r$ as the effects of $L_{m}$ under different $P_{p}$ are presented in Figure 10. It is obvious from the figure that the trend lines for $E r$ over the whole range of $P_{p}$ display a similar tendency. Er increases for the augment in $L_{m}$, and reaches a peak value at the $L_{m}$ from $64 \mathrm{~mm}$ to $82 \mathrm{~mm}$, after which the Er gradually diminishes at a relatively slower pace. A similar phenomenon was also discussed by Nakagawa et al. [35].

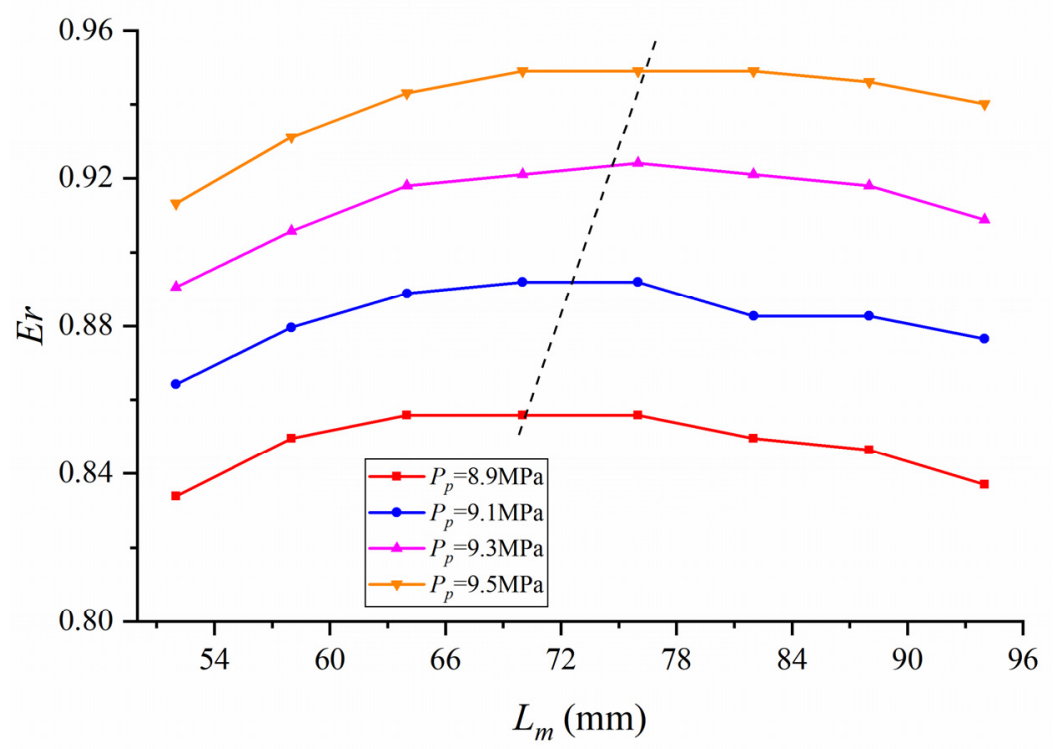

Figure 10. Variations of $E r$ with different $L_{m}$ and $P_{p}\left(D_{m}\right.$ of $8 \mathrm{~mm}, \theta_{p m}$ of $\left.60.4^{\circ}\right)$.

In terms of $P_{p}$ at $9.3 \mathrm{MPa}$, the least $E r$ of 0.891 is recorded for $52 \mathrm{~mm}$, while the greatest $E r$ of 0.924 is recorded for $76 \mathrm{~mm}$. The percentages of increase in $E r$ by varying $L_{m}$ from $52 \mathrm{~mm}$ to $94 \mathrm{~mm}$ for four sets of $P_{p}$ are $2.6 \%, 3.2 \%, 3.7 \%$ and $3.9 \%$, respectively. The broken line in the figure shows the relationship between optimal $L_{m}$ and $P_{p}$, to be specific, that the optimal $L_{m}$ of each curve representing $E r$ increases with the rise of $P_{p}$. The broken line also indicates that the optimal $L_{m}$ is not overly sensitive to the change of $P_{p}$, and the optimal $L_{m}$ is recorded from $64 \mathrm{~mm}$ to $82 \mathrm{~mm}$.

To clarify the phenomenon of Er summarized in Figure 10, the variations of axial static pressures and the partial fields of velocity in radial direction at $P_{p}$ of $9.3 \mathrm{MPa}$ are presented in Figures 11 and 12, respectively. It is observed from the Figure 11 that there is almost no distinction for axial static pressures among all the cases before the mixing chamber inlet. The velocity fields before the mixing chamber inlet among all the cases seen in Figure 12 are almost indistinguishable. This demonstrates that the effects of $L_{m}$ on flow fields before mixing chamber inlet are minimal. The differences of axial static pressures among all the cases start to be noted inside the mixing chamber. It is observed from the local enlarged image around the entrance of mixing chamber in Figure 11 that the axial static pressure representing a $L_{m}$ of $76 \mathrm{~mm}$ is the lowest, while that of $52 \mathrm{~mm}$ is the highest, which exactly proves the trend of $E r$ in Figure 10. That is to say, the changes of $P_{p}$ inside the mixing chamber are primarily responsible for the variations of $E r$. There are almost no deviations of the velocity fields inside the mixing chamber in any of the cases due to the tiny differences in pressure in Figure 12. To summarize, the relationship between $E r$ and $L_{m}$ should be taken into account when designing a two-throat nozzle ejector. 


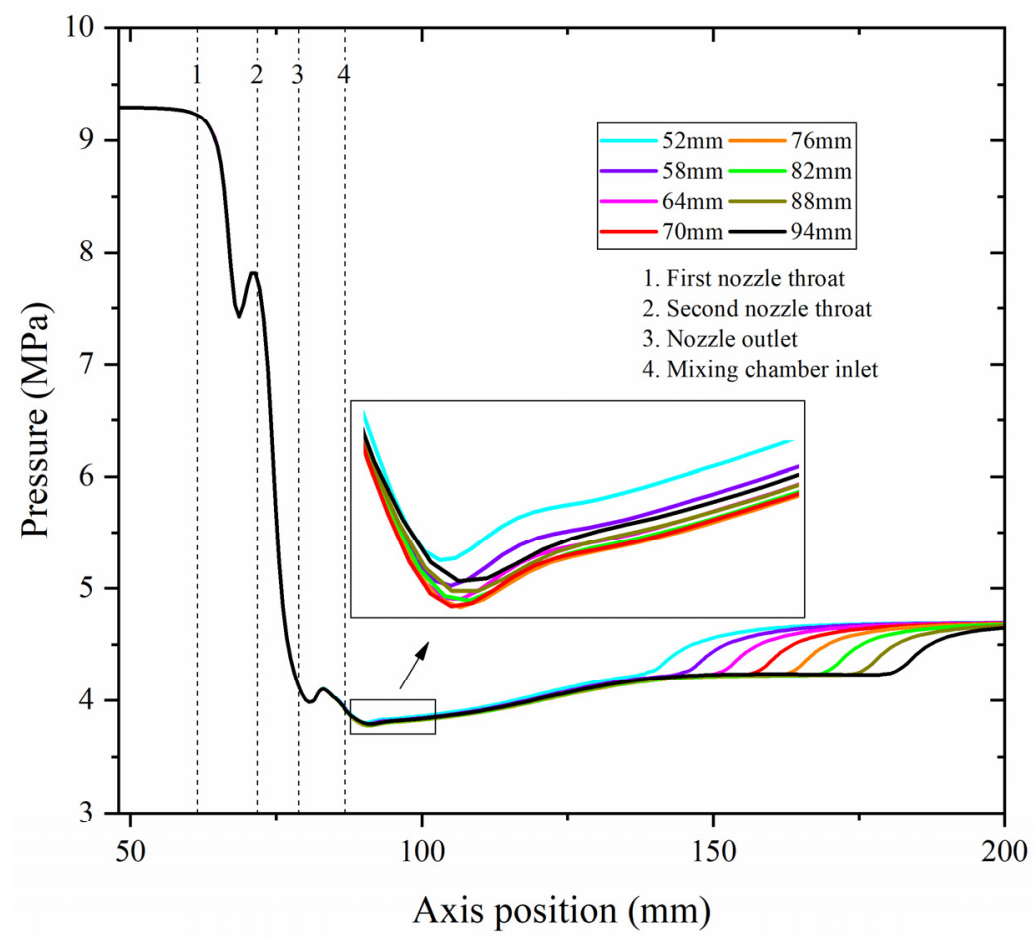

Figure 11. Variations of axial static pressures under different $L_{m}\left(P_{p}\right.$ of $\left.9.3 \mathrm{MPa}\right)$.

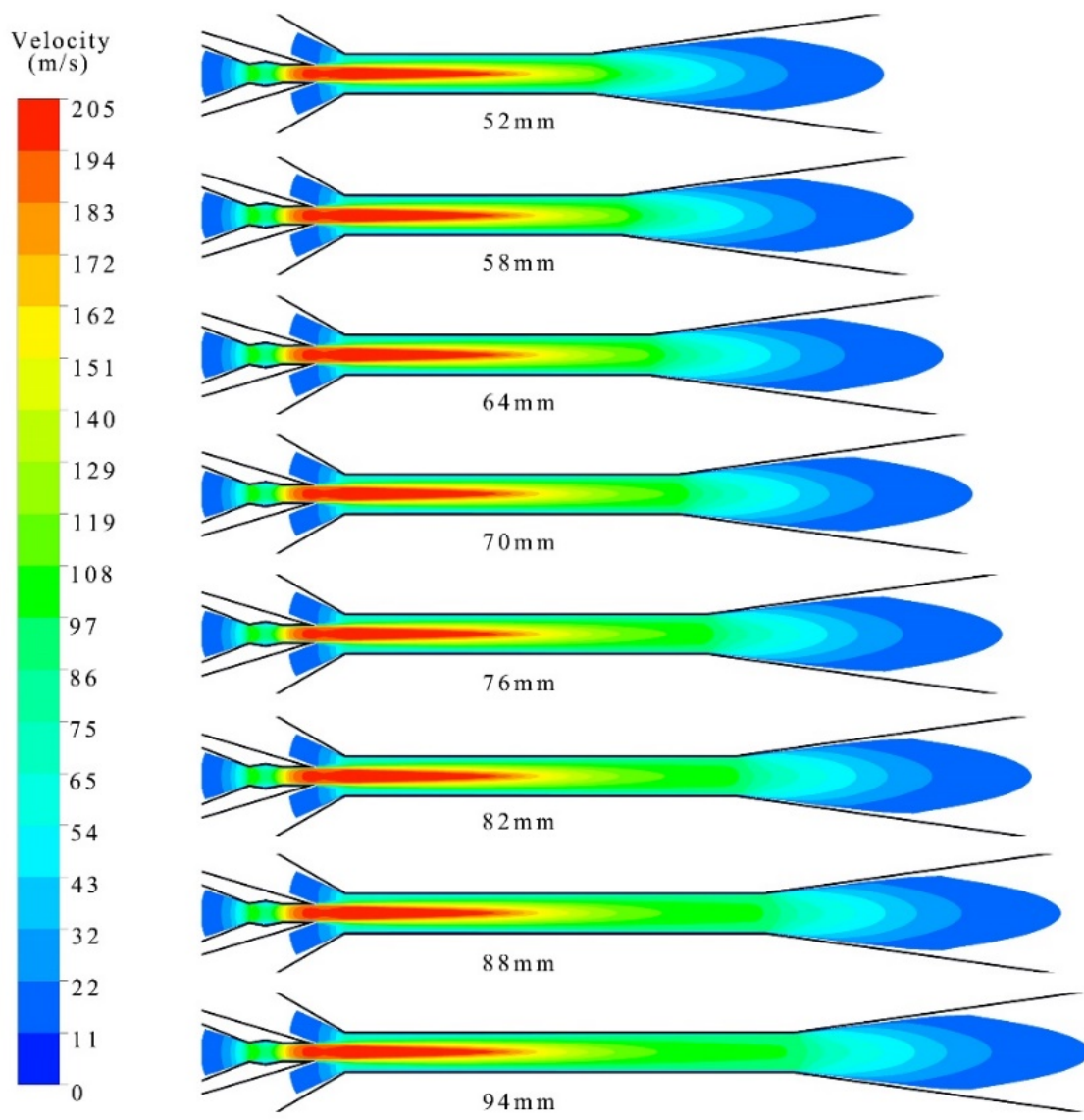

Figure 12. Fields of velocity under different $L_{m}\left(P_{p}\right.$ of $\left.9.3 \mathrm{MPa}\right)$. 


\subsection{Effects of Pre-Mixing Chamber Converging Angle on the Performance of Two-Throat Nozzle Ejector}

As presented in Figure 13, the relationship between the $E r$ and $\theta_{p m}$ can summarized under different $P_{p}$. It can be initially perceived that there is a sharp increment of $E r$ for an enlargement in $\theta_{p m}$ from $49.7^{\circ}$ to $53.5^{\circ}$ over the entire range of $P_{p}$. Er rises at a relatively lower speed along with the increase of $\theta_{p m}$ up to around $60^{\circ}$ and then attains its peak value. After $60^{\circ}$, the $E r$ starts to fall slightly. The trend of $E r$ is similar to that described in [42]. There exists little difference in the $E r$ trend for $P_{p}$ at $9.5 \mathrm{MPa}$. In terms of $P_{p}$ at $9.3 \mathrm{MPa}$, the least $E r$ of 0.863 is recorded for $49.7^{\circ}$, while the maximum $E r$ of 0.918 is recorded for $60.4^{\circ}$. The percentages of increment in $E r$ by changing $\theta_{p m}$ from $49.7^{\circ}$ to $69.0^{\circ}$ for four sets of $P_{p}$ are $9.2 \%, 7.9 \%, 6.3 \%$ and $6.0 \%$, respectively, which indicates that the $\theta_{p m}$ is of great significance for the performance of two-throat nozzle ejectors. In addition, the figure also depicts that the optimal $\theta_{p m}$ hardly changes in response to variations of $P_{p}$.

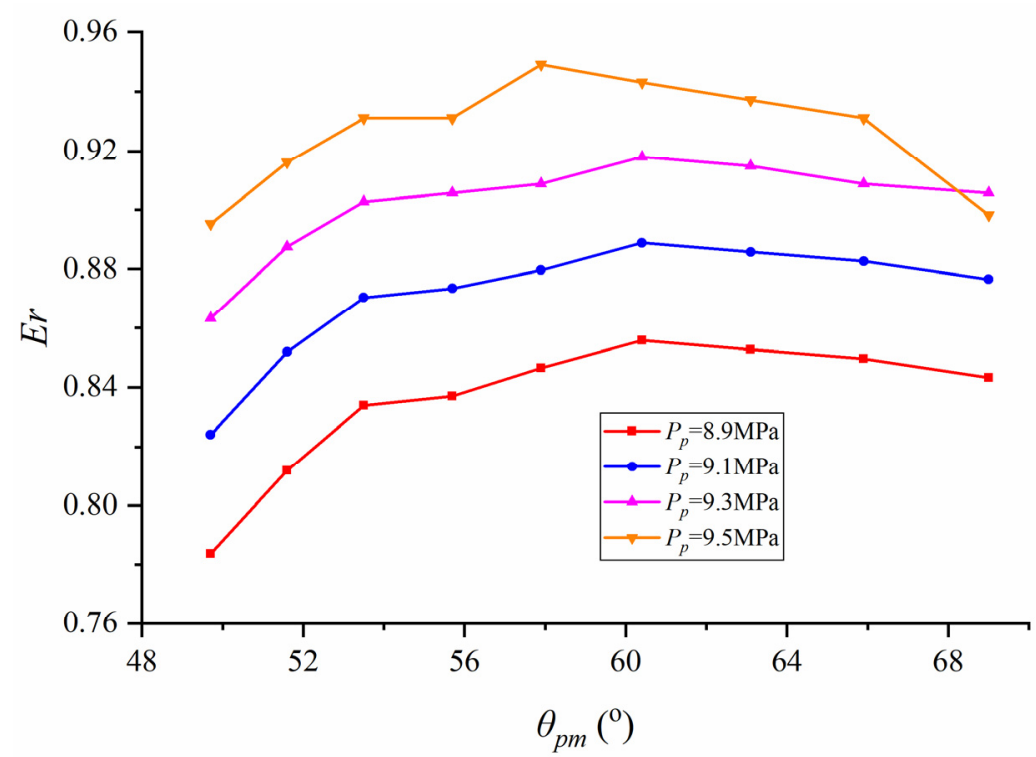

Figure 13. Variations of $E r$ with different $\theta_{p m}$ and $P_{p}\left(D_{m}\right.$ of $8 \mathrm{~mm}, L_{m}$ of $\left.64 \mathrm{~mm}\right)$.

The phenomenon of $E r$ variations with $\theta_{p m}$ in Figure 13 can be further explained with the contribution of axial static pressures distribution and distribution of velocity fields at $P_{p}$ of 9.3 MPa illustrated in Figures 14 and 15, respectively. It is noticed from Figure 14 that the curves representing axial static pressures over the total scope of cases are of no dissimilarity before nozzle outlet. The axial static pressures observed from pre-mixing chamber decrease with the increment of $\theta_{p m}$. It means that the two-throat nozzle ejectors with relatively bigger $\theta_{p m}$ own better entrainment performance, which is demonstrated by Figure 15 that the SF velocity inside the pre-mixing chamber is accelerated better. From Figure 14 it can be also noticed that the fall rate of $E r$ in pre-mixing chamber slows down with the reduction of $\theta_{p m}$. The possible reason for this can be that the decrease of $\theta_{p m}$ results in the increase of flow area, leading to more SF floods into the pre-mixing chamber to transform energy with $\mathrm{PF}$. Figure 15 presents that the PF of larger $\theta_{p m}$ keeps high velocity for longer distance at mixing chamber, which is confirmed with the aid of pressure differences inside the mixing chamber in Figure 14. And the possible reason behind this variation could be that the different levels of mixing occur between PF and SF. The relationship between $E r$ and $\theta_{p m}$ should be taken into account to design high-performance two-throat nozzle ejectors. 


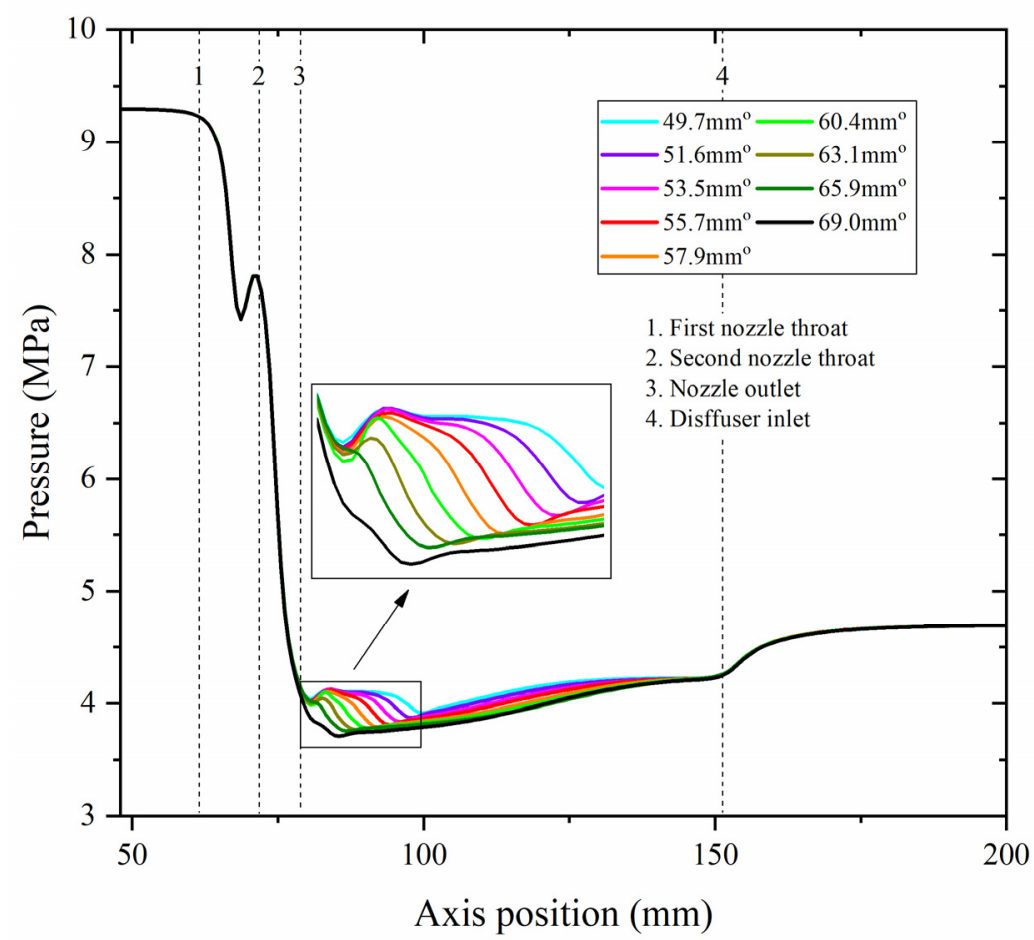

Figure 14. Variations of axial static pressure under different $\theta_{p m}\left(P_{p}\right.$ of 9.3 $\left.\mathrm{MPa}\right)$.

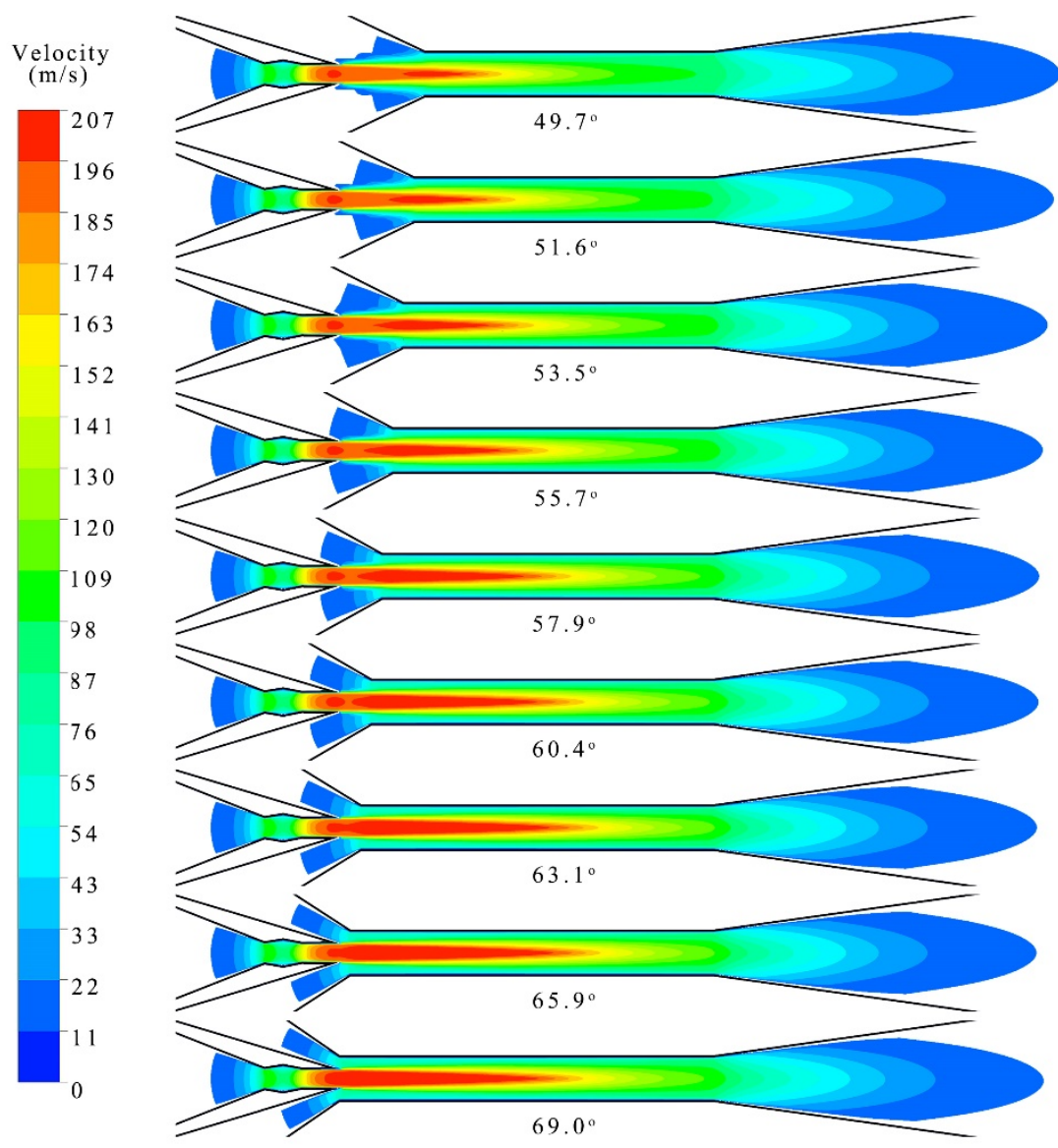

Figure 15. Fields of velocity under different $\theta_{p m}\left(P_{p}\right.$ of $\left.9.3 \mathrm{MPa}\right)$. 


\section{Conclusions}

In this study, 3D models for two-throat nozzle ejectors were developed and numerical simulations were implemented. The performance of a two-throat nozzle ejector changed with different dimensional parameters, including pre-mixing chamber converence angle, mixing chamber diameter and length, was studied under different working conditions. The simulated method was initially validated by actual experimental data from relevant literature, and then 3D models with different mixing chamber structural parameters were generated to investigate the entrainment ratio of the two-throat nozzle ejector. The influences of different mixing chamber geometries on entrainment performance were analyzed by axial static pressures and velocity fields. Based on above simulated results, the following conclusions can be drawn:

(1) The parameter $D_{m}$ is of great significance in a two-throat nozzle ejector. When the simulated $P_{p}$ ranges from $8.9 \mathrm{MPa}$ to $9.5 \mathrm{MPa}, E r$ reaches its peak value from 0.85 to 0.97 corresponding to the $D_{t}$ from $8 \mathrm{~mm}$ to $9 \mathrm{~mm}$ and there exists a tendency that the optimum $D_{m}$ increases as $P_{p}$ rises.

(2) The relationship between $E r$ and $L_{m}$ should be taken into account when designing a two-throat nozzle ejector. When the maximum $E r$ is obtained, the optimal $L_{m}$ is in the scope of $64 \mathrm{~mm}-82 \mathrm{~mm}$ with the $P_{p}$ from $8.9 \mathrm{MPa}$ to $9.5 \mathrm{MPa}$. The optimal $L_{m}$ of each curve representing $E r$ increases for the rise of $P_{p}$.

(3) The two-throat nozzle ejector performance is sensitive to the changes of $\theta_{p m}$. The percentages of increment in $E r$ by changing $\theta_{p m}$ from $49.7^{\circ}$ to $69.0^{\circ}$ for 4 sets of $P_{p}$ are $9.2 \%, 7.9 \%, 6.3 \%$ and $6.0 \%$ respectively, and the optimal $\theta_{p m}$ hardly changes in response to the variations of $P_{p}$.

The results may contribute to the prospective design work of two-throat nozzle ejector mixing chambers in refrigeration systems. The relationship between mixing chamber geometries and performance was analyzed for a certain set of working conditions. There exists an optimum $D_{m}, L_{m}$ and $\theta_{p m}$ for which a two-throat nozzle ejector achieves its maximum entrainment performance. The following research can be developed around the design of two-throat nozzle geometries to strengthen the ejector performance.

Author Contributions: Writing—original draft preparation, F.J.; writing—review and editing, D.Y. and J.X. All authors have read and agreed to the published version of the manuscript.

Funding: This research was supported by National 13th Five-Year Plan (2019YFD0901604), Science and Technology Innovation Action Plan of Shanghai Science and Technology Commission (19DZ1207503), Public Service Platform Project of Shanghai Science and Technology Commission (20DZ2292200).

Conflicts of Interest: The authors declare that they have no known competing financial interests or personal relationships that could have appeared to influence the work reported in this paper.

\section{Nomenclature}

$\begin{array}{ll}P & \text { Static pressure, } \mathrm{MPa} \\ T & \text { Static temperature, }{ }^{\circ} \mathrm{C} \\ \omega & \text { Mass flow rate, } \mathrm{kg} \cdot \mathrm{s}^{-1} \\ D & \text { Diameter, } \mathrm{mm} \\ L & \text { Length, } \mathrm{mm} \\ \theta & \text { angel, }{ }^{\circ} \\ \delta & \text { Error, } \% \\ \rho & \text { Density, } \mathrm{kg} \cdot \mathrm{m}^{-3} \\ u & \text { Vector velocity, } \mathrm{m} \mathrm{s}^{-1} \\ E & \text { Total energy } \\ \tau & \text { viscous stress, Pa } \\ t & \text { Time, } \mathrm{s}\end{array}$




$\begin{array}{ll}\text { Abbreviations } & \\ \text { CFD } & \text { Computational fluid dynamics } \\ \text { Er } & \text { Entrainment ratio } \\ \text { PF } & \text { Primary flow } \\ \text { SF } & \text { Secondary flow } \\ \text { Subscripts } & \\ p & \text { Primary flow inlet } \\ s & \text { Secondary flow inlet } \\ c & \text { Back flow } \\ m & \text { Mixing chamber } \\ p m & \text { Pre-mixing chamber }\end{array}$

\section{References}

1. Fu, W.; Liu, Z.; Li, Y.; Wu, H.; Tang, Y. Numerical study for the influences of primary steam nozzle distance and mixing chamber throat diameter on steam ejector performance. Int. J. Therm. Sci. 2018, 132, 509-516. [CrossRef]

2. Bolaji, B.O.; Huan, Z. Ozone depletion and global warming: Case for the use of natural Refrigerant-A review. Renew. Sustain. Energy Rev. 2013, 18, 49-54. [CrossRef]

3. Bodys, J.; Smolka, J.; Palacz, M.; Haida, M.; Banasiak, K.; Nowak, A.J.; Hafner, A. Performance of fixed geometry ejectors with a swirl motion installed in a multi-ejector module of a $\mathrm{CO}_{2}$ refrigeration system. Energy 2016, 117, 620-631. [CrossRef]

4. Gullo, P.; Hafner, A.; Banasiak, K. Transcritical R744 refrigeration systems for supermarket applications: Current status and future perspectives. Int. J. Refrig.-Rev. Int. Du Froid 2018, 93, 269-310. [CrossRef]

5. Karampour, M.; Sawalha, S. Energy efficiency evaluation of integrated $\mathrm{CO}_{2}$ trans-critical system in supermarkets: A field measurements and modelling analysis. Int. J. Refrig.-Rev. Int. Du Froid 2017, 82, 470-486. [CrossRef]

6. Rony, R.U.; Yang, H.J.; Krishnan, S.; Song, J. Recent Advances in Transcritical CO 2 (R744) Heat Pump System: A Review. Energies 2019, 12, 457. [CrossRef]

7. Austin, B.T.; Sumathy, K. Transcritical carbon dioxide heat pump systems: A review. Renew. Sustain. Energy Rev. 2011, 15, 4013-4029. [CrossRef]

8. Jin, Z.Q.; Eikevik, T.M.; Neksa, P.; Hafner, A. Investigation on $\mathrm{CO}_{2}$ hybrid ground-coupled heat pumping system under warm climate. Int. J. Refrig.-Rev. Int. Du Froid 2016, 62, 145-152. [CrossRef]

9. Yang, J.Y.; Yu, B.B.; Chen, J.P. Improved genetic algorithm-based prediction of a $\mathrm{CO}_{2}$ micro-channel gas-cooler against experimental data in automobile air conditioning system. Int. J. Refrig.-Rev. Int. Du Froid 2019, 106, 517-525. [CrossRef]

10. Luger, C.; Rieberer, R. Multi-objective design optimization of a rail HVAC CO 2 cycle. Int. J. Refrig. 2018, 92, 133-142. [CrossRef]

11. Kimura de Carvalho, B.Y.; Melo, C.; Pereira, R.H. An experimental study on the use of variable capacity two-stage compressors in transcritical carbon dioxide light commercial refrigerating systems. Int. J. Refrig. 2019, 106, 604-615. [CrossRef]

12. Mastrullo, R.; Mauro, A.W.; Perrone, A. A model and simulations to investigate the effects of compressor and fans speeds on the performance of $\mathrm{CO}_{2}$ light commercial refrigerators. Appl. Therm. Eng. 2015, 84, 158-169. [CrossRef]

13. Sian, R.A.; Wang, C.-C. Comparative study for $\mathrm{CO}_{2}$ and R-134a heat pump tumble Dryer-A rational approach. Int. J. Refrig. 2019, 106, 474-491. [CrossRef]

14. Mancini, F.; Minetto, S.; Fornasieri, E. Thermodynamic analysis and experimental investigation of a $\mathrm{CO}_{2}$ household heat pump dryer. Int. J. Refrig. 2011, 34, 851-858. [CrossRef]

15. Purohit, N.; Sharma, V.; Fricke, B.; Gupta, D.K.; Dasgupta, M.S. Parametric analysis and optimization of $\mathrm{CO}_{2}$ trans-critical cycle for chiller application in a warm climate. Appl. Therm. Eng. 2019, 150, 706-719. [CrossRef]

16. Li, Y.; Deng, J.; Ma, L. Experimental study on the primary flow expansion characteristics in transcritical $\mathrm{CO}_{2}$ two-phase ejectors with different primary nozzle diverging angles. Energy 2019, 186, 115839. [CrossRef]

17. Elbel, S.; Lawrence, N. Review of recent developments in advanced ejector technology. Int. J. Refrig. 2016, 62, 1-18. [CrossRef]

18. Yadav, S.K.; Murari Pandey, K.; Gupta, R. Recent advances on principles of working of ejectors: A review. Mater. Today Proc. 2021, 45, 6298-6305. [CrossRef]

19. Li, S.Z.; Li, W.; Liu, Y.J.; Ji, C.; Zhang, J.Z. Experimental Investigation of the Performance and Spray Characteristics of a Supersonic Two-Phase Flow Ejector with Different Structures. Energies 2020, 13, 1166. [CrossRef]

20. Huang, K.; Guo, X.M.; Zhang, P.L. Influence of Structural Parameters of Two-Throat Nozzle Ejector on Performance of Two-phase Flow Ejector Refrigeration System. In 8th International Conference on Applied Energy; Yan, J., Sun, F., Chou, S.K., Desideri, U., Li, H., Campana, P., Xiong, R., Eds.; Elsevier Science Bv: Amsterdam, The Netherlands, 2017; Volume 105, pp. 5091-5097.

21. Wang, X.; Wang, L.; Song, Y.; Deng, J.; Zhan, Y. Optimal design of two-stage ejector for subzero refrigeration system on fishing vessel. Appl. Therm. Eng. 2021, 187, 116565. [CrossRef]

22. Chen, G.; Zhang, R.; Zhu, D.; Chen, S.; Fang, L.; Hao, X. Experimental study on two-stage ejector refrigeration system driven by two heat sources. Int. J. Refrig. 2017, 74, 295-303. [CrossRef]

23. Chang, Y.J.; Chen, Y.M. Enhancement of a steam-jet refrigerator using a novel application of the petal nozzle. Exp. Therm. Fluid Sci. 2000, 22, 203-211. [CrossRef] 
24. Yang, X.; Long, X.; Yao, X. Numerical investigation on the mixing process in a steam ejector with different nozzle structures. Int. J. Therm. Sci. 2012, 56, 95-106. [CrossRef]

25. Wang, X.; Yu, J. Experimental investigation on two-phase driven ejector performance in a novel ejector enhanced refrigeration system. Energy Convers. Manag. 2016, 111, 391-400. [CrossRef]

26. Banu, J.P.; Mani, A. Numerical studies on ejector with swirl generator. Int. J. Therm. Sci. 2019, 137, 589-600. [CrossRef]

27. Zhou, M.; Wang, X.; Yu, J. Theoretical study on a novel dual-nozzle ejector enhanced refrigeration cycle for household refrigeratorfreezers. Energy Convers. Manag. 2013, 73, 278-284. [CrossRef]

28. Rao, S.M.V.; Jagadeesh, G. Novel supersonic nozzles for mixing enhancement in supersonic ejectors. Appl. Therm. Eng. 2014, 71, 62-71. [CrossRef]

29. Chen, X.; Omer, S.; Worall, M.; Riffat, S. Recent developments in ejector refrigeration technologies. Renew. Sustain. Energy Rev. 2013, 19, 629-651. [CrossRef]

30. He, S.; Li, Y.; Wang, R.Z. Progress of mathematical modeling on ejectors. Renew. Sustain. Energy Rev. 2009, 13, 1760-1780. [CrossRef]

31. Mohamed, S.; Shatilla, Y.; Zhang, T. CFD-based design and simulation of hydrocarbon ejector for cooling. Energy 2019, 167, 346-358. [CrossRef]

32. Kim, S.; Jeon, Y.; Chung, H.J.; Kim, Y.J.A.T.E. Performance optimization of an R410A air-conditioner with a dual evaporator ejector cycle based on cooling seasonal performance factor. Appl. Therm. Eng. 2018, 131, 988-997. [CrossRef]

33. Wang, L.; Yan, J.; Wang, C.; Li, X.B. Numerical study on optimization of ejector primary nozzle geometries. Int. J. Refrig.-Rev. Int. Du Froid 2017, 76, 219-229. [CrossRef]

34. Hou, W.; Wang, L.; Yan, J.; Li, X.; Wang, L. Simulation on the performance of ejector in a parallel hybrid ejector-based refrigeratorfreezer cooling cycle. Energy Convers. Manag. 2017, 143, 440-447. [CrossRef]

35. Nakagawa, M.; Marasigan, A.R.; Matsukawa, T.; Kurashina, A. Experimental investigation on the effect of mixing length on the performance of two-phase ejector for $\mathrm{CO}_{2}$ refrigeration cycle with and without heat exchanger. Int. J. Refrig. 2011, 34, 1604-1613. [CrossRef]

36. Zhang, H.; Wang, L.; Yan, J.; Li, X.; Wang, L. Performance investigation of a novel EEV-based ejector for refrigerator-freezers. Appl. Therm. Eng. 2017, 121, 336-343. [CrossRef]

37. Wu, H.; Liu, Z.; Han, B.; Li, Y. Numerical investigation of the influences of mixing chamber geometries on steam ejector performance. Desalination 2014, 353, 15-20. [CrossRef]

38. Dong, J.; Chen, X.; Wang, W.; Kang, C.; Ma, H. An experimental investigation of steam ejector refrigeration system powered by extra low temperature heat source. Int. Commun. Heat Mass Transf. 2017, 81, 250-256. [CrossRef]

39. Dong, J.; Hu, Q.; Yu, M.; Han, Z.; Cui, W.; Liang, D.; Ma, H.; Pan, X. Numerical investigation on the influence of mixing chamber length on steam ejector performance. Appl. Therm. Eng. 2020, 174, 115204. [CrossRef]

40. Guangming, C.; Xiaoxiao, X.; Shuang, L.; Lixia, L.; Liming, T. An experimental and theoretical study of a CO 2 ejector. Int. J. Refrig. 2010, 33, 915-921. [CrossRef]

41. Palacz, M.; Haida, M.; Smolka, J.; Plis, M.; Nowak, A.J.; Banasiak, K. A gas ejector for $\mathrm{CO}_{2}$ supercritical cycles. Energy 2018, 163, 1207-1216. [CrossRef]

42. Ramesh, A.S.; Sekhar, S.J. Experimental and numerical investigations on the effect of suction chamber angle and nozzle exit position of a steam-jet ejector. Energy 2018, 164, 1097-1113. [CrossRef] 